\section{Biothis and biothat}

\section{Walter Gratzer}

Chinese Journal of Blochemistry and Biophysics. Chairman of the editorial committee Lin Qi-Shui. Allerton, New York. 4/yr. North America \$265, elsewhere $£ 280$.

The FASEB Joumal. Editor-in-chief William J. Whelan. Federation of American Societies for Experimental Biology. 15/yr. US $\$ 200$, elsewhere $\$ 240$ (institutional); US $\$ 90$, elsewhere $\$ 130$ (personal); US $\$ 45$, elsewhere $\$ 85$ (student).

I was recently told - and I do not vouch for the veracity of the tale - that an occidental author, having sent his highly rejectable manuscript to an oriental journal, received the following response: the editors, he was informed, had found his paper so overwhelmingly superior that anything their modest organ could aspire to publish thereafter would appear irredeemably unworthy. For the sake of their survival, they were therefore desolated to have to decline his offering. The point of the story is that submissions from the outside world to parochial journals are a rare enough event to throw the editors off balance, and when such papers do arrive they are unlikely to be the sort of contribution over which the international journals of the West would fight.

So the journals of the learned societies of Europe, Asia and Africa stay hidden in decent obscurity. There are exceptions (such as arguably the Journal of Biochemistry of Tokyo and the Biochemical Journal), but in general a Ruritanian biochemist with any pride or confidence in his work will want to bring it before a wider public than is reached by Ruritanica Biochimica Acta (especially if published in the Ruritanian language). What then, if any, is the place of national journals? Primarily, it seems to me, they are an assertion of a national scientific identity and a focus for the local research community.

The launching of the new English translation of Chinese Journal of Biochemistry and Biophysics (sometime Acta Biochimica et Biophysica Sinica) is perhaps a signal that the renaissance of biological science in China is complete - that its output can fill a respectable journal of its own. This the first four issues undoubtedly demonstrate: the coverage is representative of the biochemistry and biophysics of the 1980 s and the substance is solid. It is certainly not given over, as might have been feared, to pharmacologically active products of rare oriental plants: the pages are spattered with spectra of many kinds, with restriction maps and with expression vectors. It is all respectable, if occasionally lightweight stuff.

Everyone will wish the journal good speed. It reflects a remarkable achievement. Yet one cannot help but wonder whether what will really count for Chinese science, both inside the country and abroad, may not be the papers that the authors will want to stand beside the best in the international journals.

The FASEB Journal (with somewhat similar subject matter) is an altogether different proposition - its precursor, the Federation Proceedings, had been going for 45 years, and had, it seems, the widest circulation of any biological journal. Fed. Proc. published a desultory trickle of conference proceedings the year round and came to life every spring with the Federation abstracts (usually some 7,000 of them from 20,000 participants), which all biological scientists scan keenly, to see what the opposition is up to. To judge from the President's introduction in the first issue of the reconstructed model of the FASEB Journal, two years ago, it must suddenly have dawned on the FASEB committee that they had an existing clientele, all with

\section{Small talk}

\section{Jeffrey W. Almond}

VIrus Genes. Editor-in-chief Yechie Becker. Kluwer. 4/yr. Dfl.251, United States $\$ 126$ (institutional); DfI.150, US $\$ 60$ (individual).

IN VIRUS research during the 1980 s there has been a strong emphasis on analysis of the structure and function of virus genes. This is hardly surprising, given the advances in recombinant DNA technology over this period and the realization that a detailed knowledge of virus genes is fundamental to our understanding of all aspects of virus biology. Whether this trend justifies the introduction of a new journal which aims "to serve as a platform for the publication of experimental and computer studies on genes from all virus genera and families" remains open to question. Papers dealing with virus genes already dominate most established virology journals and will continue to do so in the forseeable future.

Virus Genes is a small journal, introduced in 1987, with most issues so far containing fewer than ten papers. The journal publishes short communications and reviews as well as full papers, and welcomes letters to the editor-in-chief. In addition, some of the issues contain editorial comment and/or a rather interesting "Viewpoint" section which deals with a contentious issue of current interest in virology, usually chosen by the editor-inchief. Although the quality of production is acceptable, the small format means that open mouths, down which could be thrust something more nutritious than conference reports and abstracts.

It was, on the face of it, a foolproof formula for success. What then have the editors made of their opportunity in the intervening years? The reviews are maintaining a decent standard with only an occasional lurch downmarket; the papers are seldom notably exciting or trendy, but those I can judge are of unexceptionable quality. But there are only five of them in each monthly issue, so the President, in seeking, as he avows, to help out Nature and Science in the struggle against the ever-advancing flood of publication, is bailing with a teaspoon.

Why only five a month? Is the editorial board rejecting hundreds in the interests of lofty standards? Is there a dearth of manuscripts? Or is it simply that they cannot afford more pages? Prospective contributors need to know.

Walter Gratzer is in the MRC Cell Biophysics Unit, King's College London, 26-29 Drury Lane, London WC2B 5RL, UK. some figures and diagrams are cramped and difficult to read. There is also an annoying inconsistency in the layout of the references, some authors providing titles and others not.

In spite of my initial scepticism I have been mildly impressed by the quality of the papers published to date, although some of them seem to assume a wider remit than just virus genes. The prospects for success of this journal, however,

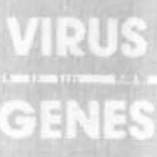

depend heavily on the quantity as well as the quality of the contributions it will attract. At the moment it is not a firstdivision journal because it does not contain enough material to make it a compulsory purchase for libraries. Moreover it does not have a unique position in the virology literature and is unlikely to establish one.

A glance at a random issue of one of the better virology journals revealed in excess of 40 papers, at least half of which were concerned with virus genes. Unless this new journal can attract a substantial proportion of these papers it is unlikely to establish itself in the top flight. I cannot see this happening with a quarterly publication schedule and with publication times certainly no shorter than those of its main competitors.

Jeffrey W. Almond is in the Department of Microbiology, University of Reading, London Road, Reading RG1 5AQ, UK.

NATURE · VOL $341 \cdot 28$ SEPTEMBER 1989 